elsewhere, "Gibson was a swift and brilliant intuitive worker. He could recognize a problem, build the apparatus, carry out the experiments and write up the results at a quite astonishing speed . . .". He was equally happy in guiding and encouraging his colleagues and research students. When he saw you baffled, he would blow a ring of tobacco smoke and say, "If I were you, I would try ....".

Gibson enjoyed good books (which he read with a speed like that of his own writing) and works of art. He detested the pompous and the shallow equally. He sought no honours, but those intimate with him saw that he was made happy and proud by such distinctions as the Ewing Medal of the Institution of Civil Engineers and the honorary degrees of LL.D. conferred upon him by St. Andrews and Manchester. It is probably true, however, that the D.Sc. which he won at Manchester fifty years ago remained his favourite.

Naturally, his name is linked most prominently with the Beyer chair in his Alma Mater (1920-49), but he spoke with great affection of his period in Dundee as professor of engineering in the University of St. Andrews (1909-20, interrupted by service during the First World War in the Army and at Farnborough).

Perhaps no truer or more fitting tribute could be paid to 'A. H. G.' by those of us who had the happy experience of being his students and colleagues than to say that we feel the same veneration for him as he felt for Osborne Reynolds. JACK ALLEN

\section{Prof. G. V. Douglas}

George Vibert Douglas died suddenly in Toronto, Canada, on October 8, 1958, at the age of sixty-six. From 1932 until his retirement in 1957 he was Carnegie professor of geology at Dalhousie University in Halifax, Nova Scotia.

\section{NEW FELLOWS OF}

A

'I a meeting of the Royal Society on March 19, the society :

Dr. G. H. Beale, senior lecturer in genetics in the University of Edinburgh (Institute of Animal Genetics), distinguished for his researches on the genetics of flower pigments and on nucleus-cytoplasm relations in Paramecium.

Prof. F. Bergel, professor of chemistry in the University of London, at the Chester Beatty Research Institute of the Institute of Cancer Research, Royal Cancer Hospital, distinguished for his work in synthetical organic chemistry in the field of vitamins and drugs.

Dr. Anv Bishop, director of the Medical Research Council Group for Research in Chemotherapy, at the Molteno Institute of Biology and Parasitology, Cam. bridge, distinguished as a protozoologist and especially for her work on the malaria parasite and its resistance to drugs.

Prof. G. E. Blackman, Sibthorpian professor of rural economy in the University of Oxford (Depart. ment of Agriculture), distinguished for his research work on the ecology of wild and cultivated plants and on weed-killers.
Prof. Douglas was born in Montreal in 1892. At McGill University he studied under F. D. Adams, but this training was interrupted by the First World War and he went overseas in 1915. He served in France and Flanders with the 17 th Battn. Northumberland Fusiliers and, for a short time, with the Royal Engineers. He was awarded the Military Cross and mentioned in dispatches. He returned to Canada in 1919. He graduated from McGill in 1920 and received his M.Sc. degree in 1921.

$\mathrm{He}$ spent the next two years in the Antarctic as geologist with Shackleton's last expedition. While working up the results of the expedition, he was able to work in the University of Cambridge. This was followed by further work at Harvard University, where he held a part-time post as instructor under Daly. In 1926, he became chief geologist for the Rio Tinto Company - at first in Spain and later on the Rhodesian Congo Border concession. In 1932 he left the Rio Tinto Company to take up the post at Dolhousie which he held for the remainder of his active life.

Prof. Douglas was a notable factor in the lives of a whole generation of students. Undoubtedly his greatest influence arose from his ability to inspire enthusiasm and to encourage the student to do the best of which he was capable. A secondary influence was his own wide-ranging interest, and one recalls vividly the stimulus of an afternoon at his home, when ideas (some good, many otherwise, no doubt) flew like shuttlecocks as the teacher encouraged his students to exercise their wits. Ideas strongly held often plunged him into controversy but, though many disagreed, there were none who did not admit his courage and integrity.

$\mathrm{He}$ is survived by his wife, two daughters and two sons, and by his sister, Dr. A. V. Douglas, of the Department of Astronomy, Queen's University, Kingston, Ontario.

G. C. Milligan

\title{
THE ROYAL SOCIETY
}

Prof. H. Bond, professor of applied mathematics in the University of London (King's College), distinguished for his contributions to cosmology, astrophysics and other branches of theoretical physics.

Prof. J. M. CAssels, professor of experimental physics in the University of Liverpool, distinguished for his studies of high-energy nuclear physics using particle-accelerating machines.

Prof. A. R. Clapham, professor of botany in the University of Sheffield, distinguished for his research upon many important aspects of ecology and taxonomy, especially those relating to British plants.

DR. F. H. C. CRICK, member of the staff of the Medical Research Council Unit for Research on the Molecular Structure of Biological Systems at the Cavendish Laboratory, Cambridge, distinguished for his contributions to molecular biology.

Mr. G. B. R. FeIlden, director of research, Ruston and Hornsby, Ltd., Lincoln, distinguished for his application of scientific principles to the development and design of industrial gas turbines.

Dr. D. W. W. Henderson, director of the Ministry of Supply Microbiological Research Establishment, 